\title{
SOCIAL FUNCTION RECONSTRUCTION OF INTELLECTUAL PROPERTY RIGHTS (IPR) BASED ON JUSTICE VALUES
}

\author{
Anis Mashdurohatun \\ Faculty of Law, UNISSULA Semarang \\ Email : anism@unissula.ac.id
}

\section{Hayyan UI Haq \\ Faculty of Law UTRECHT UNIVERSITY, Netherland}

\author{
Sony Zulhuda \\ Faculty of Law, IIUM Malaysia
}

The purpose of this study is to examine and to analyze the construction of social functions of Intellectual Property Rights. Furthermore, it is also intended to know the urgency of social functions of Intellectual Property Rights and to reconstruct the social function of Intellectual Property Rights based on the value of Justice. The method used was doctrinal and non doctrinal approach by using primary and secondary data source. Moreover, the data was analyzed by using analytical descriptive. The result of the research shows that, the construction of social function of IPR has not been in accordance with Pancasila justice value. The urgency of social functions of IPR is as a form of crystallization of communal, inclusive and religious values. While the reconstruction of the social function of IPR was based on the value of Justice, namely by harmonizing the principle of Corporate Social Responsibility with the crystallization of communal, inclusive and religious values in using the IPR products, especially for copyrights and patents.

Keywords: Reconstruction, IPR Social Function, Justice Value

\section{A. Introduction}

IPR is the material right, the right to an object that comes from the brain work, the work of the ratio of human reasoning. The work of the reasoning ratio is in the form of immaterial objects that are intangible objects ${ }^{1}$. IPR is closely related to intangible objects and

${ }^{1}$ Look H. OK. Saidin, Aspek Hukum Hak Kekayaan Intelektual (Intellectual Property Rights), PT. Raja Grafindo Persada, Jakarta, 2003, page. 9. 
protects intellectual works created from human inventions, tastes and intentions $^{2}$. In the Indonesian legal system, moving objects are divided into tangible moving objects and intangible moving objects. IPR is a part of the property rights of an immovable moving object ${ }^{3}$.

"One of the biggest roadblocks to self-archiving is the copyright policies of publishers, which may not allow or allow self-archiving with associated riders. Intellectual Property Rights (IPRs) issues and content licensing are major policy issues from creation and depositing content in an Institutional repository (IR). ${ }^{\prime 4}$

Thomas Jefferson contradictory said that a person may have exclusive rights over an idea that comes from his or her mind, as long as he is able to keep the idea for himself and not spread to others. However, when the idea is revealed and spread to others, the existence of the idea becomes public property. Jefferson's thinking emphasizes that an idea embodied in a useful work should be allowed to spread from one person to another throughout the world for the benefit of the development of the quality of life and morals. The spread of an idea can be categorized as Divine Rights ${ }^{5}$.

This protection is meant to create an ideal legal framework for expanding broader public access to any essential product in the field of

${ }^{2}$ Look Tomi Suryo Utomo, Hak Kekayaan Intelektual (HKI) Di Era Global Sebuah Kajian Kontemporer, Graha Ilmu, Yogyakarta, 2010, Page.1.

${ }^{3}$ Look Budi Santoso, Op. Cit. page. 34. Further explained that IPR is a daily issue, from verbal to digital. Look Budi Santoso, HKI (Hak Kekayaan Intelektual), Pustaka Magister, Semarang, 2011, page.1. S circulated by the writer HKI is something that adheres and adheres to every human being in the activities of everyday life, both as a consumer and as a creator and or inventor in the field of Science, art and literature as well as in the field of technology.

4 Shashi Nath, S; B, Sridhara; Joshi, C.M; Puneet Kumar, Puneet Kumar, Intellectual Property Rights: Issues for Creation of Institutional Repository, Journal of Library \& Information Technology, Delhi, 09/2008, Volume 28, Issue 5. Page 49.

${ }^{5}$ See Kinney \& Lange PA, Intellectual Property Law For Business Lawyers, ST. Paul Minn West. Publishing Co, USA, 1996, Page 2. 
food, agriculture, health and education in order to maintain the sustainability of collective life. ${ }^{6}$

It is interesting to examine the construction of the social function of Intellectual Property Rights in Indonesia, its urgency as well as the ideal construction of IPR social functions in Indonesia in the future especially in copyrights, brands and patents. research result Anis Mashdurohatun \& M.Ali Mansyur states that The development of economic law will be able to improve national competitiveness, generating high economic growth and quality to reduce poverty and reduce unemployment and needs to be done,so that ultimately the legal function as a system that maximizes the welfare of society. ${ }^{7}$

\section{B. Research Methods}

Research method is defined as a way to find the right answers of the law problems ${ }^{8}$. Tis section discussed the approach method, the nature and stages of the study.

This study used two types of research that is doctrinal and nondoctrinal legal research ${ }^{9}$. Doctrinal legal studies are used to find positive legal materials used to address the problem of IPR social construction, which required the support of these materials. The first

${ }^{6}$ Hayyan ul Haq, Creating Appropriate Legal Framework in the Utilization of Intellectual Property Products, Journal of International Commercial Law and Technology Vol.9, No.2 (2014) Page.69.

7 Anis Mashdurohatun \& M. Ali Mansyur, Product Capabilities Dynamic on Industrial Design Carved Wood in Small and Medium Enterprises (SMES) Jepara Furniture in Promoting the Protection of Intellectual Property Rights, International Journal of Applied Engineering Research ISSN 0973-4562 Volume 12, Number 19 (2017) page. 8220-8221.

${ }^{8}$ Adi Sulistiyono, Disertasi Mengembangkan Paradigma Penyelesesain Sengketa Non-Litigasi dalam Rangka Pendayagunaan alternatif Penyelesaian Sengketa Bisnis/Hak Kekayaan Intelektual, Program Doktor Ilmu Hukum UNDIP, Semarang, 2002, page.33. see Setiono, Pemahaman Terhadap Metode Penelitian Hukum, Program Studi Ilmu Hukum UNS, Surakarta, 2005, Page 19

${ }^{9}$ Soetandyo Wignyosoebroto, Hukum : Paradigma, Metode dan Dinamika Masalahnya, Elsam dan HUMA, Jakarta, 2002, page.146. 
step taken was through an inventory of legal principles and IPR legislation. Non-doctrinal legal research was used to obtain materials to help answering the problem about the urgency of the social function of IPR as a form of communal crystallization, religious and inclusive values of the Indonesian nation. Including primary data sources were phenomena that exist in the field associated with the focus of research.

\section{Rresearch Result and Discussion}

The social function of IPR-it is more commonly conceived in IPR legislation with the term limitation of rights. But in various countries both in civil law system and common law system it is known as fair use or fair dealing. While in the terms of TRIPs Agrement, it is called the term public interest.

Copyright restrictions are governed by Articles 43 to Article 49 of Law No. 28 of 2014 on Copyright (hereinafter written as copyright law). Subject to the provision, an act which is not considered as a copyright infringement if: it is non-commercial, and there is permission from the creator. In the name of usage, retrieval, reproduction and/or alteration of a substantially all-or-substantial Work of Submissions and/or Products shall not be deemed a copyright infringement if the source is mentioned or fully listed without prejudice to the reasonable interests of the Author or Rightsholder; and for the educational purposes.

The principle of the social function of land rights in theory is the recognition of the interests of individuals, social interests and public interest in land ${ }^{10}$

${ }^{10}$ Triana Rejekiningsih, Asas Fungsi Sosial Hak Atas Tanah Pada Negara Hukum (Suatu Tinjauan Dari Teori, Yuridis Dan Penerapannya Di Indonesia), Yustisia. Vol. 5 No. 2 Mei-Agustus 2016. Page.298. 
Copyright grants certain exclusive rights to its owner. Based on these rights, the copyright owner can copy the work, issue copies of the work to the public, rent or lend the work to the public, perform, show or play the work in public, communicate the work to the public (including broadcasting and electronic transmission), and can adapt of the work or do any of the above in relation to an adaptation. Copyright is said to be infringed when one of the exclusive rights of the owner is performed by a party without the consent or authorisation of the owner. This infringement is called primary infringement. ${ }^{11}$

Pancasila is the main basic values which is as crystallization of various values that live in society. It is the soul of the nation (volksgeist) in society and nation of Indonesia which is the guiding star (leidstar) in the life of society, nation and state of Indonesia.

Collectivism means the same as kinship or gotong-royong that describe the original social life pattern of the people in the archipelago. Hatta understood that collectivism in social interactions and product processes in the countryside. The contents are mutual help. Collectivism contains 2 (two) elements of common property and common effort. In traditional village societies, it is reflected in the land that is shared and worked together. Thus, collectivism is translated into the collective possession of the means of production, which is cultivated together to meet common needs.

Bung Karno interpreted kinship as a spirit of mutual cooperation, while Soepomo interpreted more kinship as a biological-

\footnotetext{
${ }^{11}$ Shashi Nath, S; B, Sridhara; Joshi, C.M; Puneet Kumar, Puneet Kumar, Op.Cit.Page.50. in the framework of IPR protection, especially the copyright needs a balance between the interests of the creator and the public interest as the user of creation. This is as discussed by Bhatnagar, Harshita; Mishra, Vinay V , ISP liability for third party copyright infringement: a comparative analysis for setting international standard norms, to create an international standard guideline and in doing so the point that the individual countries legislations wont have an effective control over the problem has been highlighted and this is the reason why an international body like WIPO and WTO has to enter to control the situation.
} 
organist concept. Therefore, in an integralistic state the nature of Indonesia's original governance, according to Soepomo, leaders united with the people and leaders must uphold unity and maintain balance in society. This is Soepomo's interpretation of the concept of "manunggaling kawulo lan gustt". The unity between the leaders and the people, among the factions of the people, is bound by the spirit held by the Indonesian people, namely the spirit of kinship and the spirit of mutual cooperation.

The nature of commun or community, is a typical feature of the Indonesian people who are still living very isolated or in daily life is still very dependent on the land or nature in general. In such a society there is always a whole-hearted nature, preferring the common good rather than the interests of the individual. Villagers, hamlets, always play a decisive role whose judgments and decisions should not and can not be wasted. The decision of the village is severe, applicable and in all circumstances must also be obeyed with respect and solemnity ${ }^{12}$.

Achmad Sanusi asserted in terms of the nature of commun, everyone feels himself as a member of society not as a stand-alone person regardless of his equal counterparts, he accepts rights and assumes obligations according to his position. One's personal interests are always balanced by the common good. That is the same with one's personal rights always balanced by the common good. Subjective rights are exercised with due regard to their social functions. He is committed to his fellowman, to his Adat Chief and to his people. Born the conviction of the necessity of helping please, gotong royong, sambat sinambat in doing something of interest in society. The ways of acting

12 See Tolib Setiady, Intisari Hukum Adat Indonesia dalam Kajian Kepustakaan, Cetakan ke-2, Alfabeta, Bandung, page 39. 
in social or legal relationships are always accompanied by principles of deliberation, harmony, peace, decisions and justice ${ }^{13}$.

Although the Indonesia nation is a nation born because of pluralism and differences united by the collective consciousness to live as an independent and sovereign nation. Founding fathers agree upon Pancasila, which is the crystallization of the noble values of the nation, and establishes it as the basis of the state. His inclusivism as the principle of life is full of diversity and plurality ${ }^{14}$, but with the noble intention and put aside the interests of the group, religion and class, with the motto of Unity in Diversity unity and unity still intertwined ${ }^{15}$.

The basic values of Indonesianism are clearly illustrated in the values of Pancasila which contain the values of spiritualism, collectivity, and inclusiveness. This basic value of Indonesia forms the basis of the social function of property rights in the fulfillment of fundamental rights of society, in the utilization of intellectual work products.

Social justice shows the circumstances in which there are norms of society that are recognized and implemented in an orderly manner by members of the community. This can really happen if every member of the community has implemented all the principles of Pancasila as a whole in everyday life. Then public figures and national leaders continually advocate the consideration of social and moral considerations in economic activity. This means the existence of a great desire to apply the principles of Pancasila, especially the principles of

${ }^{13}$ Ibid, page 39-40.

${ }^{14} \mathrm{http}: / /$ islamlib.com/id/artikel/mengukuhkan-visi-kebangsaan-pesantren

15 translated word, bhinneka that means "diversity" or different. The word neka in Sanskerta that's mean "various" and become a word-former "aneka" in Indonesian Language. The word tunggal means "one". word ika means "that". Literally Bhinneka Tunggal Ika translates into "diversity that one Itu", meaningful though different but in essence the Indonesian nation remains a unity. This motto is used to describe the unity and unity of the nation and the Unitary State of the Republic of Indonesia consisting of diverse cultures, regional languages, race, ethnicity, religion and beliefs. http://id.wikipedia.org/wiki /Bhinneka Tunggal Ika. 
the Godhead of the One and the principle social justice for all the people of Indonesia. For example, the enthusiasm of a company that cares for the greatest desires regardless of the interests of others, is clearly incompatible with the moral of Pancasila.

Social justice is a problem that has long been concerned by scholars. The Indonesian nation includes social justice for all the people as the ultimate goal described as a just and prosperous society, which is a blessing of its secrets, a just and prosperous society. Since it is the final manifestation of society contains the properties to complete justice and prosperity. It includes legal, economic, political, socio-cultural and moral justice.

Social justice for all the people of Indonesia is realized through the realization of the principle of justice in every aspect of justice that is law, political economy, social culture and morals are all closely related ${ }^{16}$. Therefore, the values of Pancasila have constitutive functions that determine whether the Indonesian rule of law is the correct legal order, in addition to the regulative function that determines the positive law prevailing in Indonesia is a fair law or not ${ }^{17}$.

Thus the Fifth Precept of Pancasila, social justice for all Indonesian people, is not implied the formulation of highlighted selfinterest, but the interests of the whole Indonesian people. The values contained therein are as follows: (1) developing noble deeds, reflecting the attitude and atmosphere of kinship and mutual cooperation; (2) developing a fair attitude toward others; (3) maintaining a balance between rights and obligations; (4) respecting the rights of others; (5) likes to give help to others to stand on their own; (6) does not exercise

${ }^{16}$ See Mubyarto, Ekonomi Pancasila Gagasan dan Kemungkinan, LP3ES, Jakarta, 1987, page.206.

17 See Hamid A.S. Attamimi, Pancasila sebagai Ideolagi dalam Berbagai Bidang Kehidupan Masyarakat, Berbangsa dan Bernegara, BP-7 Pusat, Jakarta, 1991, page 24. 
proprietary rights to extortion attempts against others; (7) does not exercise proprietary rights for extravagant and lavish lifestyles; (8) does not exercise proprietary rights to the contrary to or prejudice the public interest; (9) likes to work hard; (10) likes to appreciate the work of others beneficial to progress and common welfare; (11) likes to do activities in order to realize the progress of equitable and social justice.

According to Koentjaraningrat, the cultural value system is the most abstract level of customary. A cultural value system consists of conceptions that live in the minds of most citizens about things that they consider valuable in life. Therefore, cultural value subsystems usually serve as the ultimate guideline for human behavior. Such a value system seems to be the guide of individuals in society ${ }^{18}$. Therefore, the value system that is constantly internalized in the individual will form the mental attitude or attitude as expected.

One of the recommended arrangements is to maintain the harmony of life with others and forbid the actions that can interfere with peace. The concept of harmony or understanding alignment was very prominent in the appreciation of the people of Indonesia. What is sought is not victory but harmony and balance ${ }^{19}$. Therefore the importance of value development and improvement of individual ethics in order to live as harmonious as possible with others ${ }^{20}$. So to realize the harmony and regularity of people's lives, each individual is encouraged to abstain from acts that injure the rights and interests of others, which is demanded not a certain inner attitude but how to behave in society ${ }^{21}$.

18 See Kontjaraningrat, Kebudayaan: Mentalitas dan Pembangunan, Gramedia Pustaka Utama, Jakarta, 2004, page 25.

${ }^{19}$ See Franz Magnis Suseno, Kuasa dan Moral, Gramedia Pustaka Utama, Jakarta, 2001, page.168.

20 See Franz Magnis Suseno, Etika Jawa: Sebuah Analisa Falsafi tentang Kebijaksanaan Hidup Jawa, Gramedia Pustaka Utama, Jakarta, 2003, page.227.

${ }^{21}$ Ibid, page.80. 
The values and ethics of respect for the rights and respect for the interests of others are still felt today. With or without the rule of law, cultural values and ethics are alive and well preserved. The noble ethical concepts still govern the behavior of people's lives because they believe in order. The strength of ethical doctrines still continues to maintain a harmonious social relationship. The concept of order based on values and cultural ethics remains in modern times, especially the development of the global economy. Harmonious relationships among people, between Creator and society, and between Creator and country, are a conducive vehicle in improving creativity create, so the atmosphere of social life that respects and respects the rights of others that encourage actualization of one's creative potential.

A creator is guided by the norm to make the most of his creations. Just like other property rights, society is guided by the norm to respect the rights attached to the creation. The balance norm places the rights of the creator with restrictions in order to achieve equality with his obligations. This creator does not put forward the monopoly by mastering and exploiting his creations ${ }^{22}$, but the creation is provided to be used for the benefit of society. This thinker is in line with the principle of human social function and property rights in society. In this case the human social function is reflected in the habit of "gugur gunung" which means donating power for the public interest, while the social function of property rights is reflected by giving permission to the

${ }^{22}$ See Rahmi Jened, Penyalahgunaan Hak Eksklusif Hak Kekayaan Intelektual, Disertasi, Program Doktor Program Pascasarjana Universitas Airlangga, Surabaya, 2006, page 245. 
villagers to also savor or enjoy his things ${ }^{23}$. Culture according to Koentjaraningrat ${ }^{24}$ has at least 3 (three) forms:

a. culture as a set of ideas, ideas, values and norms and regulations;

b. culture as a series of activities of patterned human behavior in society;

c. culture as objects of human works.

All copyright protection systems base its core thinking on cultural values, especially ethical values ${ }^{25}$. The values of ethics and cultural order in the era of the $19^{\text {th }}$ century greatly colored the idealism of protection against the feelings of the creator, especially the creator's personality expressed in every work of his creation.

According Soerjono Soekanto, Indonesian customary law simply recognizes the immaterial right, for example the right to a certain custom title which a person possesses because of his position in the society or the right that belongs to someone who makes ornaments of paintings on his boat on the island of Key and a particular motif on the fabric found in Minangkabau ${ }^{26}$. Then also the Creator of Ornaments, they do not recognize as their property and do not feel violated their rights when others imitate the ornaments they made. There is pride because his work is liked and beneficial to others. This also happens to the creation of songs or traditional songs, pantun, and folklore, so no name (no name) or unknown who the real creator.

\footnotetext{
${ }^{23}$ See Soerojo Wignjodipoero, Pengantar dan Asas-Asas Hukum Adat, Cetakan ke6, Gunung Agung, Jakarta, 1983, page 60.

24 See Koentjaraningrat, Apakah Nilai Gotong Royong Itu Menghambat Pembangunan Masyarakat Desa di Indonesia, Fakultas Ekonomi Universitas Indonesia, Jakarta, 1984, page 5.

${ }_{25}$ See W.R. Cornish \& Llewelyn D, Intellectual Property: Patent, Copyrights, Trademark and Allied Rights, Sweet 7 \& Maxwell, Fifth Edition, London, 2003, page 452.

${ }^{26}$ See Soerjono Soekanto, Asas-Asas Hukum Adat, Rajawali Press, Jakarta, 2005, page.200-201.
} 
The concept of property belonging to a communal society has the characteristic that property rights serve the public interest. The concept of indigenous property rights of Indonesia can be drawn from customary law especially with respect to land rights based on ulayat rights. Ulayat right is an authority under customary law owned by the customary law community over a specific area which is the living environment of the community to take benefit from natural resources (including land), for survival and life. The right arises outwardly and inwardly and uninterruptedly between the customary law community and the territory concerned. The relationship contains authority and obligations. This right is still recognized by Law Number 5 Year 1960 on Basic Regulation of Agrarian Principles, among others in Article 3. Then Article 5 and Article 67 of Law Number 41 Year 1999 regarding Forestry ${ }^{27}$. Individuals as members of the community may control and own certain roles of the communal land by clearing the land, maintaining it and utilizing it. The control of the land is attached to 4 (four) characteristics: (1) No absolute ownership; (2) Inclusive; (3) Prohibition to trade land; and (4) is more valued by man and his work than land.

Togetherness in customary law is meant that in customary law it is more priority to the common interest, in which self-interest is covered by mutuality. One for all and all for one, the legal relationship between members of indigenous peoples is based on a sense of togetherness, kinship, help and mutual help ${ }^{28}$.

${ }^{27}$ See Maria Sri Wulani Sumarjono, Tanah dalam Perpektif Hak Ekonomi, Sosial, dan Budaya, Kompas, Jakarta, 2008, page.170.

28 Dewi Wulansari, Hukum Adat Indonesia, PT. Refika Aditama, Bandung, 2010, page 17. 
Surojo Wignjodipuro ${ }^{29}$ in his book entitled "Pengantar Dan AsasAsas Hukum Adat" explains that the universal values in customary law are composed of:

a. The principle of mutual cooperation (Gotong-royong)

Mutual cooperation becomes a habit for the community, it is seen in community activities, such as gugur gunung or consecration work in building and maintaining water channels to irrigate the fields, village mosque, embankment that protect the village against the danger of flooding, streets village and others. In addition, the habit of a person who owns a rice field must allow free-field rice from higherlying rice fields, flowed through rice fields / land, also obliged to allow the villagers, during the non-tandur season (as long as the fields are not planted), shepherding livestock free in the fields.

b. Human social function and belonging in society

The human social function is reflected in the gugur gunung activity of the community mountain in establishing and maintaining all physical and nonphysical goods that are in the public interest. Whereas the social function of the property appears also in the habit of the owner allowing the sedesanya citizens at certain times or in certain circumstances using his own.

Thus human social function and property in society is a form of society habits individually or collectively, they have been willing to give services, energy, time or property that is material or non material for the sake of common interest or public interest.

${ }^{29}$ See Surojo Wignjodipuro, Pengantar dan Asas-Asas Hukum Adat, Cetakan ke-7, PT. Gunung Agung, Jakarta, 1984, page 59-60. 
c. The principle of consent as the basis of common power

d. The principle of representation and deliberation in the system of government

F.D. Holleman, who was a professor in the subject of customary law in Leiden who succeeded Van Vollenhoven, in his inauguration speech entitled De Commune Trek In Het Indonesische Rechtsleven, summarizes the four general attributes of Indonesian customary law, the first of the magical religio, the second communal nature, the three contant properties and the four concrete properties (virsuil).

Soerjono Soekanto ${ }^{30}$ citing Hazairin's opinion in his book "Pancasila's Democracy" outlines that customary law communities in all parts of Indonesia, in their community of communal character, where mutual help, helping to feel and have a big role. Furthermore it is explained that the elements of the social system will be found as follows: "General morals are highly respected and supervised together. Legal cases are solved primarily with the aim of maintaining peace, ... customary chiefs are in charge of all fields, capturing, examining, punishing, forgiving, providing conditions for freedom. Individual rights, especially on land, have many conditions to enhance their social functioning. ... Customary law run by adat head is a traditional law passed down from ancestors, which is modeled according to the times.

Thus, the local values of customary law used in developing social functions in the work of book copyright in the provisions of positive law are as follows: (1) the virtues of virtue, humility, respect and friendship; (2) the value of mutual help and help; (3) the value of a steady sense of belonging as a direct reflection of the humility that causes us not to be called by others but we are not willing to take anybody; (4) values

30 See Soerjono Soekanto, Hukum Adat Indonesia, PT. RajaGrafindo Persada, Jakarta, 1981, page 11-12. 
that reflect a strong fraternal fraternity among the members of society, and (5) the value of respecting and appreciating the work of others. Corporate social responsibility or commonly known as the name CSR (Corporate Social Responsibility) ${ }^{31}$ is a corporate commitment aimed at continuing economic activity, which is widely related to internal and external parties. The broad concept relates to the company's obligation to maximize the positive impact of the company on society.

Corporate Social Responsibility (CSR) is positive, means the company does not conduct activities that economically benefit the company but in social terms harm the interests and social welfare, but otherwise the company in conducting activities not only based on the calculation of profit and loss alone, but also based on social welfare considerations $\mathrm{s}^{32}$.

CSR bases the activities of the company on the interests and social welfare of the community in harmony with the results of the WIPO Panel in Paris, France on 2-3 February 2011 on The Sixth Global

${ }^{31}$ Corporate Social Responsibility (tanggung jawab sosial perusahaan) Dalam Pasal 1 angka 3 Undang-Undang Nomor 40 Tahun 2007 on Limited Liability Companies, explain that Social and Environmental Responsibility is the company's commitment to participate in sustainable economic development in order to improve the quality of life and the environment that is beneficial both for the company itself, the local community, and the community in general.

${ }^{32}$ See Ridwan Khairandy, Corporate Social Responsibility (CSR), lectures FH UII, Yogyakarta, 2012, page 1-2. It further explained that this is a reaction to Entity Theory. This theory views the corporation as a social institution operating to benefit many interested groups (Stakeholder) ) which are not only shareholders, but also employees, government, and the general public. On progress, Yusuf Wibisiono, in his book "Dissecting Concepts and Applications of CSR" says that the business world is increasingly recognizing that the company is no longer faced with the responsibilities it rests on the single bottom line, that corporate value which is reflected in its financial condition, but also must pay attention to social and environmental aspects. The business world is no new creating profit for the sake of continuity of his business, but also the responsibility to the social and the environment. See Gunawan Widjadja and Jeremiah Ardi Pratama, Legal Risk \& Corporate Business Without CSR, Penebar Swadaya, Jakarta, 2008, page 18. It further explained that the corporation is not a separate entity from a society and the environment in which it exists, but the corporation is an integral part can only exist if it has strong social legitimination. To have strong social legitimacy, a corporation must have many benefits and care for its social environment and become good corporate citizenship. Ibid, page 5 . 
Congress on Counterfeiting and Piracy, the outcome of which is reflected below:

1) The panel supported WIPO's initiative to further explore the potential of CSR in the context of creating an environment within which to respect IP rights.

2) Foreign investment is to be seen in the broader context of respecting the rule of law. In this sense, creating an environment in which property (including IP) is protected can have positive effects on investment.

3) Addressing counterfeiting and piracy requires thinking beyond IP enforcement as such. It should be a long-term investment aiming at long-term partnerships in which a company becomes "a citizen" of the local community. In this regard, CSR can be an important tool to build mutual trust and respect.

4) Sustainable anti-counterfeiting approaches require an understanding of the impact of enforcement action in a broader sense, linking enforcement to a country's long term development goals.

5) Enforcement officials need to understand reasons and socioeconomic benefits of protecting IP, rather than merely applying the law.

6) Consumer awareness remains crucial. In that context, greater commitment by consumer associations and groups would be desirable.

The exploitation, maintenance and enforcement of intellectual works, may utilize several legal instruments, both derived from normative provisions such as (patent law, copyright) and contracts. In the use of normative provisions, these, researchers, inventors 
and patent holders may use the articles governing registration, exploitation-license, and cancellation. Furthermore, in the use of contract instruments, researchers, inventors, and patent holders can look at emerging legal issues, both at the pre-contract, contract and post-contract stage. At the pre-contract stage, the legal issue relates to the identification of the legality or validity of the object and the subject of the license agreement. At the pre-contract stage, interested parties need to scrutinize the contents of the contract to be contracted, especially with regard to business restriction practices, such as (i) tying clauses-including tie-ins, and tie-outs; (ii) price fixing; (iii) package licensing, (iv) field of use restrictions and territorial exclusivisity; (v) grant-back provisions; (vi) limitations on transferee with respect to research and development, quality control clauses, exclusive sales or representation agreements, production volume restrictions, export restrictions, and other restrictions. Because of the contents of this contract that will be the basis of legal protection for the parties in the exploitation of research-technology products. Furthermore, at the post-research stage, the legal protection for the utilization of the results of this research can be done by utilizing the role of substance and legal structure. In this case, the substance of the law is the normative provisions that regulate and oversee the implementation of technology exploitation, such as the articles on licensing, licensing registration, public interest, national interests, social functions, and others. While the legal structure is law enforcement officers associated with the implementation of commercialization of technology, such as patent apparatus, law enforcement, police, prosecutors, judges, lawyers. ${ }^{33}$

${ }^{33}$ Hayyan UI Haq, Strategy and Momentum of Constructing Legal Protection in Identifying 


\section{Conclusion}

The construction of the social function of IPR has not been in accordance with the Pancasila justice value. The urgency of social functions of IPR as a form of crystallization of communal, inclusive and religious values. While reconstructing the social function of IPR based on Justice value, that is by harmonizing the principle of Corporate Social Responsibility (CSR) with crystallization of communal, inclusive and religious values which in the use and utilization of IPR products especially copyright and patent.

\section{BIBLIOGRAPHY}

Adi Sulistiyono, Disertasi Mengembangkan Paradigma Penyelesesain Sengketa Non-Litigasi dalam Rangka Pendayagunaan alternatif Penyelesaian Sengketa Bisnis/ Hak Kekayaan Intelektual, Program Doktor Ilmu Hukum UNDIP, Semarang, 2002.

Budi Santoso, HKI ( Hak Kekayaan Intelektual), Pustaka Magister, Semarang, 2011.

Bushar Muhammad, Asas-Asas Hukum Adat (Suatu Pengantar), Pradnya Paramita, Jakarta, 1978

Dewi Wulansari, Hukum Adat Indonesia, PT. Refika Aditama, Bandung, 2010.

F.D. Holleman, De Commune Trek In Het Indonesische Rechtsleven, Leiden, 1935.

and Exploiting Research Results, Paper on the Training of Intellectual Property Management (TOT-HAKI) Manager of Indonesian Universities, 2004, organized by Director of Research Development and Dedication at the Society, Directorate General of Higher Education, Ministry of National Education, Republic of Indonesia, at Hotel Millennium, Jakarta, September 22, 2004. 
Franz Magnis Suseno, Etika Jawa: Sebuah Analisa Falsafi tentang Kebijaksanaan Hidup Jawa, Gramedia Pustaka Utama, Jakarta, 2003.

Franz Magnis Suseno, Kuasa dan Moral, Gramedia Pustaka Utama, Jakarta, 2001.

Gunawan Widjadja dan Yeremia Ardi Pratama, Risiko Hukum \& Bisnis Perusahaan Tanpa CSR, Penebar Swadaya, Jakarta, 2008.

H. OK. Saidin, Aspek Hukum Hak Kekayaan Intelektual (Intellectual Property Rights), PT. Raja Grafindo Persada, Jakarta, 2003.

Hamid A.S. Attamimi, Pancasila sebagai Ideolagi dalam Berbagai Bidang Kehidupan Masyarakat, Berbangsa dan Bernegara, BP-7 Pusat, Jakarta, 1991.

http://id.wikipedia.org/wiki/Bhinneka Tunggal Ika.

http://islamlib.com/id/artikel/mengukuhkan-visi-kebangsaan-pesantren.

Koentjaraningrat, Apakah Nilai Gotong Royong Itu Menghambat Pembangunan Masyarakat Desa di Indonesia, Fakultas Ekonomi Universitas Indonesia, Jakarta, 1984.

Kontjaraningrat, Kebudayaan: Mentalitas dan Pembangunan, Gramedia Pustaka Utama, Jakarta, 2004.

Maria Sri Wulani Sumarjono, Tanah dalam Perpektif Hak Ekonomi, Sosial, dan Budaya, Kompas, Jakarta, 2008.

Mubyarto, Ekonomi Pancasila Gagasan dan Kemungkinan, LP3ES, Jakarta, 1987, page. 206.

Rahmi Jened, Penyalahgunaan Hak Eksklusif Hak Kekayaan Intelektual, Disertasi, Program Doktor Program Pascasarjana Universitas Airlangga, Surabaya, 2006.

Ridwan Khairandy, Corporate Social Responsibility (CSR), bahan Kuliah FH UII, Yogyakarta, 2012.

Setiono, Pemahaman Terhadap Metode Penelitian Hukum, Program Studi Ilmu Hukum UNS, Surakarta, 2005.

Shashi Nath, S; B, Sridhara; Joshi, C.M; Puneet Kumar, Puneet Kumar, Intellectual Property Rights: Issues for Creation of Institutional Repository, Journal of Library \& Information Technology, Delhi, 09/2008, Volume 28, Issue 5. 
Shashi Nath, S; B, Sridhara; Joshi, C.M; Puneet Kumar, Puneet Kumar.

Soerjono Soekanto, Asas-Asas Hukum Adat, Rajawali Press, Jakarta, 2005.

Soerjono Soekanto, Hukum Adat Indonesia, PT. RajaGrafindo Persada, Jakarta, 1981.

Soerojo Wignjodipoero, Pengantar dan Asas-Asas Hukum Adat, Cetakan ke-6, Gunung Agung, Jakarta, 1983.

Soetandyo Wignyosoebroto, Hukum: Paradigma, Metode dan Dinamika Masalahnya, Elsam dan HUMA, Jakarta, 2002.

Sofian Effendi, Sistem Pemerintahan Adalah Jati Diri Bangsa, UGM, Yogyakarta, 2005.

Surojo Wignjodipuro, Pengantar dan Asas-Asas Hukum Adat, Cetakan ke7, PT. Gunung Agung, Jakarta, 1984.

Tolib Setiady, Intisari Hukum Adat Indonesia dalam Kajian Kepustakaan, Cetakan ke-2, Alfabeta, Bandung.

Tomi Suryo Utomo, Hak Kekayaan Intelektual (HKI) Di Era Global Sebuah Kajian Kontemporer, Graha IImu, Yogyakarta, 2010.

Triana Rejekiningsih, Asas Fungsi Sosial Hak Atas Tanah Pada Negara Hukum (Suatu Tinjauan Dari Teori, Yuridis Dan Penerapannya Di Indonesia), Yustisia. Vol. 5 No. 2 Mei - Agustus 2016.

Undang-Undang Nomor 40 Tahun 2007 tentang Perseroan Terbatas.

W.R. Cornish \& Llewelyn D, Intellectual Property: Patent, Copyrights, Trademark and Allied Rights, Sweet 7 \& Maxwell, Fifth Edition, London, 2003. 